\title{
Flow Hydrograph Analysis in Watershed of Krueng Seunagan Nagan Raya District
}

\author{
$1^{\text {st }}$ Muhammad Ikhsan \\ Civil Engineering Faculty of Engineering, \\ Teuku Umar University \\ Aceh Barat, Indonesia \\ mikhsanrustam@gmail.com
}

\author{
$2^{\text {nd }}$ Inseun Yuri Salena \\ Civil Engineering, Faculty of Engineering, \\ Teuku Umar University \\ Aceh Barat, Indonesia \\ Inseunsalena@utu.ac.id
}

\author{
$3^{\text {rd }}$ Ayu Aidar \\ Civil Engineering, Faculty of Engineering, \\ Teuku Umar University \\ Aceh Barat, Indonesia \\ abuyasin@gmail.com
}

\begin{abstract}
Seunagan, Nagan Raya District is a lowland area that often-experiencing flooding that comes from the overflow of the Krueng Seunagan River. This condition affects the activity of peoples living in the river environment. Based on the problems occurred, this research is conducted to determine the characteristics of river hydrograph in the Watershed Krueng Seunagan, based on visible river condition so it is necessary to predict how big of river flow discharge with upstream and downstream hydrographs on the Seunagan River Basin and variation of coefficient value $K$ and $X$ in Muskingum method Chunge. Primary data in use in the form of Speed and Depth of the river. Watershed maps and Land Use maps are used as secondary data. The results showed the average peak discharge in upstream is $17.26 \mathrm{~m} 3 / \mathrm{s}$, while the peak discharge at downstream is $11.00 \mathrm{~m} 3 / \mathrm{s}$. The peak discharge is precisely at the 19th point upstream and the point 20 downstream which is the middle of the river. The value of $K$ obtained from the calculation is 2164,383 , while the value of $X$ is 0.386 . The average value of inflow in upstream is 5.36, while the outflow is 5.37. The average value for the downstream inflow is $\mathbf{4 . 6 0 6}$, while the value in outflow is 4.601. The flow hydrograph shows the differences in the initial value of the outflow input have no major effect on the resulting discharge and the value is almost equal to the end of the hydrograph.
\end{abstract}

Keywords- Flood, Hydrograph, Discharge, Flow Search, Muskingum-Chunge

\section{INTRODUCTION}

Floods that occur almost every year due to overflowing water Krueng Seunagan river always felt by the people who are in the area of the river surroundings, especially villages Langkak, Kuala Tuha and surrounding areas. This area is located on low land, so that when it rains continuously occurs water will easily flow and cause a flood. The impact is very affected by the people who live on the river Seunagan and fishermen who cross the river every day.
Flooding is a count of flood hydrographs at a river site based on flood hydrographs in other locations. Flood hydrograph can be traced through a river basin with the aim of knowing the flood hydrograph of a site with no water-level observation, short-term flood forecasting, and downstream hydrograph calculations based on upstream hydrographs. One method of hydrological flood search is the Muskingum Method [6].

Based on the description, it is neces sary to conduct research on flow hydrograph analysis on the Seunagan River Basin in Nagan Raya District, the condition of the river is visible so it is necessary to predict how much the flow of river flow with upstream and downstream hydrograph picture on the Seunagan River Basin. As well as the upstream and downstream hydrograph characteristics. Distance from upstream to downstream that is reviewed is $1370 \mathrm{~m}$ long. Distance point of each segment is $3 \mathrm{~m}$.

\section{LITERATURE STUDY}

\section{A. Discharge}

Discharge or stream data is the most important information for water resources managers. Peak discharge (flood) is needed to design flood control buildings. While small flow discharge data is needed for planning of water allocation (utilization) for various purposes, especially in a long dry season [6].

The commonly applied method for establishing river flow is the cross-sectional profile. In this method discharge is the result of multiplication between the vertical cross-sectional area of the river (river profile) with the velocity of water flow, as the formula below:

$\mathrm{Q}=\mathrm{A} \cdot \mathrm{V}$ 
A hydrograph is a diagram illustrating a variation of discharge or water level by time. The curve provides an overview of the various conditions that exist in the area. If the characteristics of the flow area are changed then the form hydrograph will also undergo a change. The main purpose of unit hydrograph is to analyze flood control projects. The main factors for determining the hydrograph form are the watershed and climate characteristics. Climate elements that need to know are the total amount of rainfall, rain intensity, rainfall duration, rainfall distribution and temperature [1].

A hydrograph is a curve that gives the relationship between flow and time parameters. These parameters are usually in the form of flow depth or flow discharge, so there are two kinds of hydrograph that are water hydrograph and discharge hydrograph.

\section{B. Flow Routing}

Flow routing is a procedure for determining flow time and flow (flow hydrograph) at a point in a flow based on a hydrograph known upstream. If the flow is flooded then the procedure is known as flooding. Flow routing is mostly done in a flood control study, which needs to be analyzed for flood trips / flooding along rivers or reservoirs. With this flood routing if the hydrograph upstream of the river or reservoir is known it will be able to calculate the form of flood hydrograph in the downstream [7].

\section{Muskingum Method}

According to Soemarto the way of flooding that often used is the way Muskingum, which only applies under the following conditions:

a. There are no creeks that enter into the longitudinal section of the riverbed under review.

b. Addition or loss of water by rainfall, inlet or outflow of water and evaporation, are all ignored. [5].

The method of routing flood through a widely-used river is the Muskingum Method. This method modeled the volume of flooded containers in the river channel, which is a combination of prism and wedge storage. The water depth in the river depends on the inflow, outflow, and river hydraulic characteristics. As shown in the figure, the prism shell formed by the river's cross-profile along the channel has a constant volume. At the time of the coming flood, the inflows are bigger than the outflow to form a wedge [7].

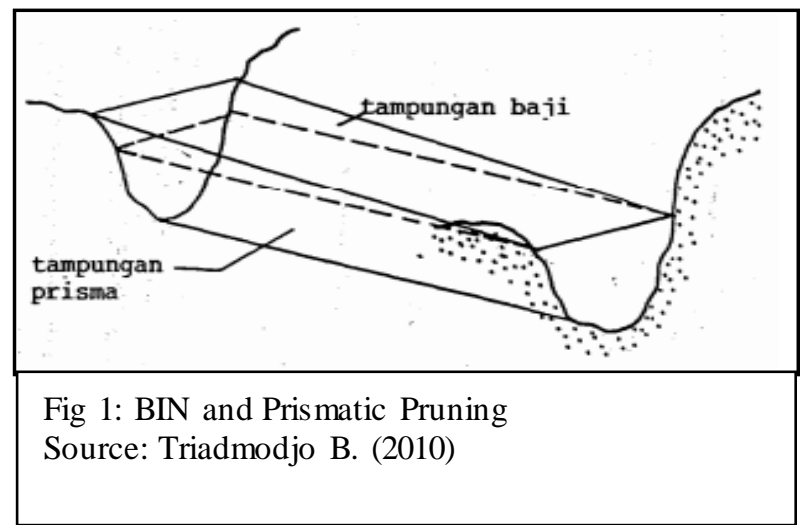

The basic principle of settling the flood calculation by the Muskingum method is the completeness of the measurement data of the upstream and downstream river flows obtained at the same time. This measurement is very important to obtain the value of the catch that occurred at the cross section of the river being reviewed. This value will be used to determine the value of $X$ and $K$ (Arifiani, et al, 2008). Equation (2.2) in the form of finite difference for the time interval $\Delta t$, as shown below:

$0 j+1=C 0 I j+1+C 1 I j+C 20 j$

Equation (2) calculates the outflow at the end of the time interval based on the inflow and outflow at the beginning of the interval and the inflow at the end of the interval. The relationship between the inflow and outflow on the routing of a river trap is shown below. The coefficient $\mathrm{C}$ in equation (2) is obtained from the equation as follows:

$$
\begin{aligned}
& C 0=-K X+0,5 \Delta t / K-K X+0,5 \Delta t \\
& C 1=K X+0,5 \Delta t / K-K X+0,5 \Delta t \\
& C 2=K-K X-0,5 \Delta t / K-K X+0,5 \Delta t
\end{aligned}
$$

\section{Development of Muskingum-Chunge Method}

Ponce (1989) developed the Muskingum-Cunge method with the same principle, but gave a fairly simple analys is that made it easier to use[6]. The data used are upstream hydrograph flow and river geometry, which is the result of hydrograph flow downstream as well as at points along the watershed. Ponce (1989), also provides a fairly simple method of settling the Muskingum-Cunge Method as follows:

$$
0 j+1=C 1 I j+C 2 I j+1+C 30 j
$$

With the search parameters are as follows:

$$
\begin{aligned}
& \boldsymbol{C} 1=\frac{\Delta \boldsymbol{t} / \mathrm{K}-2 \mathrm{X}}{2(1-\mathrm{x})+(\Delta t / \mathrm{k})} \\
& \boldsymbol{C} 2=\frac{\Delta \boldsymbol{t} / \mathrm{K}+2 \mathrm{X}}{2(1-\mathrm{x})+(\Delta t / \mathrm{k})} \\
& \boldsymbol{C} 3=\frac{2(1-\mathrm{X})-\Delta t / \mathrm{K}}{2(1-\mathrm{X})+(\Delta t / \mathrm{K})}
\end{aligned}
$$

Where $\mathrm{X}$ and $\mathrm{K}$ values are calculated by Equation:

$$
\begin{aligned}
& \mathrm{K}=\Delta \boldsymbol{L} / \boldsymbol{C} \\
& \mathrm{X}=0.5-\boldsymbol{Q p} / 2 \operatorname{So} B C \Delta \boldsymbol{L}
\end{aligned}
$$


Using equation 2.7, 2.8, and 2.9 data inflow and outflow Q1 equal to initial inflow value then Q2 can be calculated by using the formula:

$$
\mathrm{Qj}+1=\mathrm{C} 1 \mathrm{I}_{\mathrm{J}+1}+\mathrm{C}_{2} \mathrm{I}_{\mathrm{J}}+\mathrm{C}_{3} \mathrm{Q}_{\mathrm{J}}
$$

\section{RESEARCH METHODOLOGY}

This research was conducted in Langkak Village, Krueng Seunagan, Kuala Pesisir Sub-District, and Nagan Raya District. The data that will be used in this planning is data. The speed and cross section of the river is directly obtained from field research and Watershed map and Land Use map.

\section{A. Velocity Data}

Measure the flow velocity by repeatedly performing repetitions so as to get the average value of velocity on each segment using a buoy, and direct velocity data obtained from field research results.

Tools needed to get speed data:

a) Empty Jerry can or can be replaced with other light objects.

b) Stopwatch or another time meter (watch / hand phone) equipped with a stop watch.

c) Long gauge (meter or wood which is then measured in length by meter).

The steps to implement the measurements are:

a) Use floating objects (jerry can, buoys, corks, etc.) that can flow along the water stream and are unaffected by the wind.

b) Release the floating object at the start point simultaneously by pressing the stop watch and press stop at the end of the track and calculate the time (T).

c) Record the travel time of the floating object and calculate the average time.

d) Calculate the velocity (V) using the average crosssectional area variable (A) and the mean time (T) according to the formula.

e) Calculate the water discharge (Q) flowing according to the formula.

\section{B. River dimension data}

River dimension data is data that is directly taken in the research location by measuring the width of the river by using the meter. This data is measured to find out how big the dimensions of the existing river in Krueng Seunagan watershed.

1. Tools used:

a. Wooden stakes

b. Rope

c. Boat

d. Meter

Measurement steps: a. Pair the wooden peg at Point a River or river starting point.

b. Then tie the string to the wood that has been paired at point

c. Bring the rope across the river or point B b(2) bagt.

d. Then after arriving in point B mark the rope so as not to forget.

e. After that return again the starting point or point $A$, measure the string by using the meter to get the dimensions of the river.

\section{River depth data}

Depth data of this river is measured directly in Research Sites that are in Krueng Seunagan Watershed. This data is used to draw the cross-sectional shape of the river

1) The tools used in river depth measurement are:
a. Wood $\pm 5 \mathrm{~m}$
b. Rope
c. Meter
d. Isolation
e. Boat

2) The steps of river depth measurement are:

a. For the parang river to be some point

b. The distance between point 0 to point 1 is $3 \mathrm{~m}$

c. Then use the boat to help the shaving process.

plug the wood in the river to the bottom of the river.

After that mark, the wood that is on the boundary of river water using isolation

a. Then measure by using the meter to get the depth of the river.

b. Do it the same way up to the last point.

\section{Data Analysis}

If the measurement and calculation of discharge and calculation of flood routing using Muskingum-Chunge method are done, the next thing is data processing. The steps taken are as follows:

1. Create a discharge rating curve to determine the relationship the water level $(\mathrm{h})$ with time $(\mathrm{t})$ to obtain the discharge flow equation,

2. Make hydrograph of flood discharges to illustrate the variation of discharge $(\mathrm{Q})$ or water surface by time $(\mathrm{t})$, upstream and downstream flow areas of Krueng Seunagan sub-watershed.

3. Comparing the outflow of observation and outflow counting the Seunagan Basin.

\section{E. Flood Routing using the Muskingum-Chunge Method}

The steps to work on the Muskingum-Chunge method are as follows:

1. Enter the data of the cross-sectional area and the water velocity data, using Equation 2.1.

2. Calculate the value of $\mathrm{K}$ and $\mathrm{X}$ by using equations 2.8 and 2.9.

3. Calculate the coefficients of $\mathrm{C} 1, \mathrm{C} 2$, and $\mathrm{C} 3$ by using equation 2.7 . 
4. Calculating the value of outflow by entering the initial value of inflow is the value of outflow equal to the initial value of inflow by using equation 2.10 .

5. Creating outflow flow hydrograph using the MuskingumChunge method.

\section{RESULT}

\section{A. Characteristics of Krueng Seunagan Watershed}

Geographically, the Seunagan Watershed is located between 04001'16.987 "- 04026'0.940" LU and 96011'45.417 "-96051.4000" BT. Viewed from the topographical limit of the Krueng Seunagan watershed to the north is limited by the Tamiang watershed, to the east bordered by the Kuala Trang Watershed, the Tadu Watershed, the Tripa Basin, to the South bordered by the Indonesian Ocean and west by the Meurebo River.This research was conducted in Langkak Village, Kuala Pesisir sub-district, Nagan Raya District.

\section{B. Land Use in Kreung Seunagan}

The most dominant use of land in Seunagan village is the area of primary dryland forest and the remaining unpowered land, plantations, rice fields, residential areas and roads. The largest land use is more for pimer dryland forest which reaches $38.82 \%, 21.85 \%$ secondary forest, $19.44 \%$ bush / shrub, mixed dryland farming $7.82 \%, 5.65 \%$ rice field, dryland farming $2.93 \%, 1.15 \%$ swamp forest, $0.93 \%$ open land, $0.69 \%$ water body, $0.67 \%$ plantation, and the smallest is $0.05 \%$. The land use maps of the Krueng Sunagan Basin can be grouped into several land uses, each of which is presented in Table 1.

Table 1: Percentage of Land Use

\begin{tabular}{|l|l|l|}
\hline Land Use & Wide (Km2) & $\%$ \\
\hline Swamps & 11,43 & 1,15 \\
\hline Primary Dryland Forest & 384,6 & 38,82 \\
\hline Secondary Dryland Forest & 216,45 & 21,85 \\
\hline Settlement & 0,45 & 0,05 \\
\hline Plantation & 6,64 & 0,67 \\
\hline Dryland Agriculture & 29,04 & 2,93 \\
\hline Dryland Farm Mixed & 77,51 & 7,82 \\
\hline Rice fields & 55,99 & 5,65 \\
\hline Shrubs & 192,6 & 19,44 \\
\hline Open Land & 9,23 & 0,93 \\
\hline Waterbody & 6,83 & 0,69 \\
\hline Total & 990,77 & 100 \\
\hline
\end{tabular}

Source: BAPPEDA Nagan Raya District (2016)

\section{Calculation of River Flow Speed}

The function of flow measurement is to know how much water flows in a river and how fast it flows within a second. The overall length of the river from the upstream downstream that is reviewed is $1370 \mathrm{~m}$. The width of the upstream section is about $114 \mathrm{~m}$. Which is around the river is the plantation of the population. While on the downstream river about $116 \mathrm{~m}$ wide, located approximately $100 \mathrm{~m}$ from the settlement.

\section{Measurement of river flow}

A commonly applied method for determining river flow is the river profile method (cross section). In this method, the discharge is the result of multiplication between the vetal cross-sectional areas of the river (river profile) with the velocity of water flow. Measurement of flow velocity is done by first measuring river width and river flow velocity upstream and downstream. And Seunagan Krueng by directly measuring upstream and downstream at the site of the research review. The value of the obtained debit is the value of the primary data.

This value is obtained from the measurement conducted in the research location, this value is the value of river depth and river flow velocity. From the measurements that have been done, the average river depth value is $2.57 \mathrm{~m}$ for the upstream and $2.51 \mathrm{~m}$ for downstream then the average river flow rate is $0.60 \mathrm{~m} / \mathrm{s}$, upstream and $0.57 \mathrm{~m} / \mathrm{S}$ downstream. For an average discharge of $5.36 \mathrm{~m} 3 / \mathrm{s}$, while downstream with an average discharge of $4.60 \mathrm{~m} 3 / \mathrm{s}$. For data processing that has been done then can be seen on graph relation of water level (h) with flow debit (Q) or usually called rating curve.

Basically, the coefficient value of roughness along the river varies. This depends on several factors such as river irregularity, land use change, and sedimentation. From the data management that has been done then can be seen in the graph relation of water level (h) with flow debit (Q) or usually called the discharge rating curve.

From the rating curve shows that along with the increase \$of water level (h) then the flow of flow (Q) is increasing as well. Given the equation \$ of curve rating on the upstream R2 $=0.8271$ and at the downstream section obtained the curve rating equation $\mathrm{R} 2=0.9088$. As shown in the following graph:

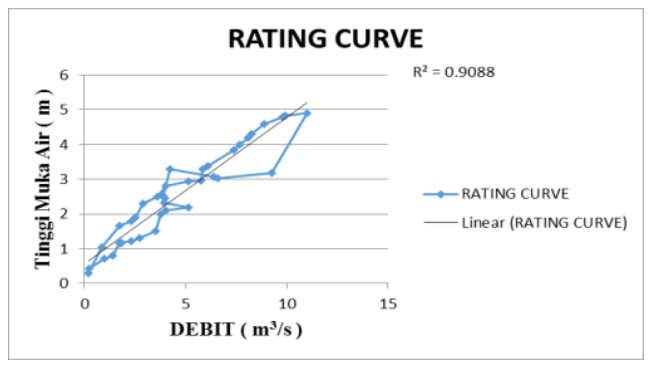

Fig 2 : Rating Curve upstream of the Seunagan Watershed 


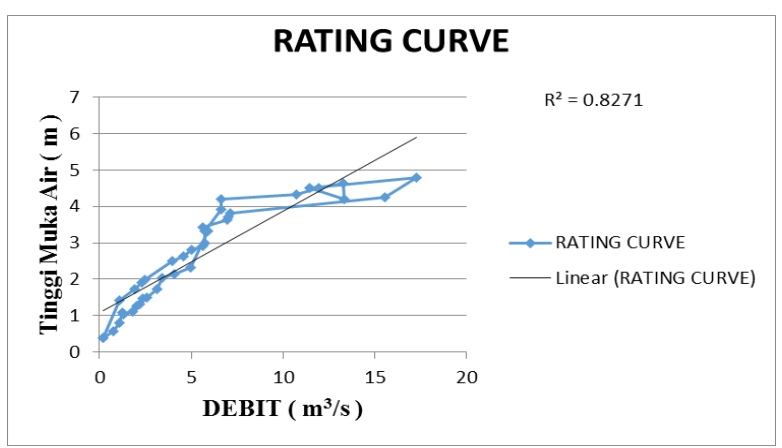

Fig 3: Rating Curve downstream of the Krueng Seunagan Watershed

\section{E. Hydrograph flood search using Muskingum-Chunge method}

Chunge 1969, developed the Muskingum Method for river excavation without lateral flow, but obtained the value of the search parameter $(\mathrm{Ci})$ directly. This method requires the inflow hydrograph data [6].

Table 2: $\mathrm{K}$ and $\mathrm{X}$ coefficient Muskingum-Chunge Method

\begin{tabular}{|c|c|c|}
\hline \multicolumn{3}{|c|}{ MUSKINGUM-CHUNGE } \\
\hline PERIOD & K (s) & $\mathrm{X}$ \\
\hline Hydrograph & 2164,383 & 0,386 \\
\hline
\end{tabular}

Table 2 shows the calculated $\mathrm{K}$ value at 2164,383 s and the $\mathrm{X}$ value at 0.386 in the flow hydrograph. If the value of $\mathrm{K}$ and $\mathrm{X}$ is in can then calculated the value of $\mathrm{C} 1+\mathrm{C} 2+\mathrm{C} 3$ with $\Delta \mathrm{t}$ is 1 hour. So from calculation in can $\mathrm{C} 1=0,31$. $\mathrm{C} 2=0.84$. $\mathrm{C} 2=-0.15$. Which is the value of $\mathrm{C} 1+\mathrm{C} 2+\mathrm{C} 3=1$. The flow hydrograph using the Muskingum-Chunge method is shown in the figure below:

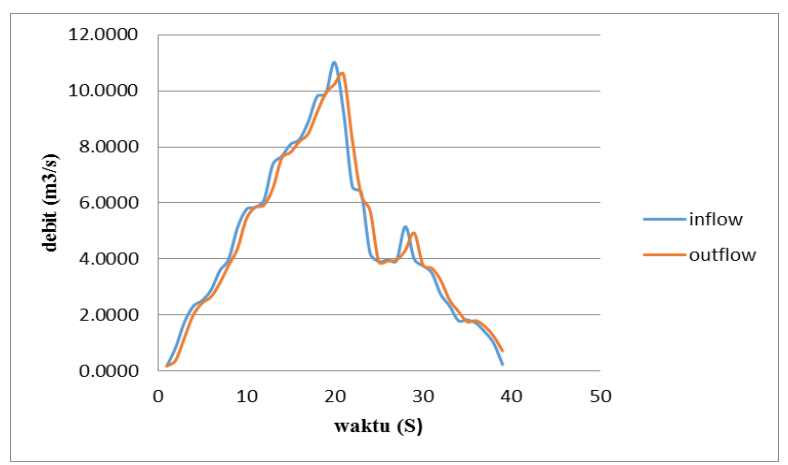

Fig 4: Hydrograph upstream of the Seunagan Basin

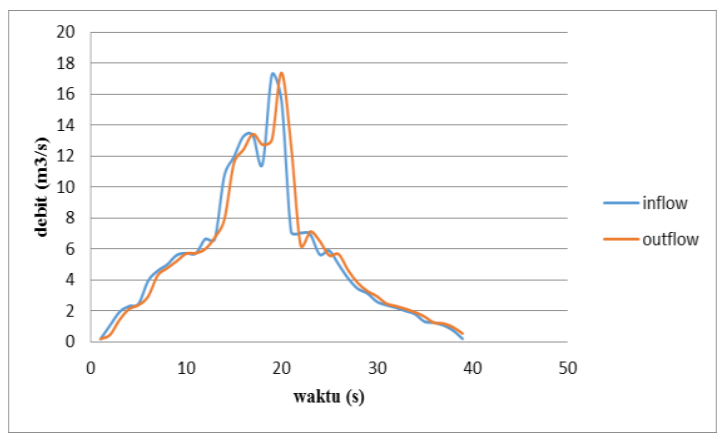

Fig 5: Hydrograph downstream of the Seunagan River Basin

Fig 4 and 5 show a flow Routing graph using the MuskingumChunge Method. In this method, the inserted data is the input value of the inflow with the outflow value with some input initial value that is the outflow value equal to the initial value. This is done to determine the value of outflow inputs suitable for the use of the Muskingum method so that the outflow discharge outcome is closest to the outflow result at the time of measurement. The peak discharge rate of the upstream inflow can be $17.26 \mathrm{~m} 3 / \mathrm{s}$. While the outflow peak discharge value $17.37 \mathrm{~m} 3$ / $\mathrm{s}$. While the peak discharge rate of downstream inflow at $11,00 \mathrm{~m} 3 / \mathrm{s}$. While the outflow peak discharge value $11.17 \mathrm{~m} 3 / \mathrm{s}$. The flow hydrograph with the Muskingum method shows that the difference in the initial value of the outflow input does not have a large effect on the resulting discharge, the resulting discharge value is almost equal to the end of the hydrograph upstream.

\section{CONCLUSION}

Based on the results of analysis and the descriptions presented in the previous chapters, it can be concluded as follows: The peak discharge rate of upstream inflow was 17.26 $\mathrm{m} 3 / \mathrm{s}$, and for the outflow peak discharge rate was $17.37 \mathrm{~m} 3 /$ $\mathrm{s}$, while the peak downstream inflow value was $11.00 \mathrm{~m} 3 / \mathrm{s}$, and the outflow peak discharge value was $11,17 \mathrm{~m} 3 / \mathrm{s}$. The flow hydrograph with the Muskingum method shows that the difference in the initial value of the outflow input has no significant effect on the resulting discharge, the resulting debit value is almost equal to the end of the hydrograph. Muskingum-Chunge method, is very appropriate to use because it can be seen from the calculation results obtained and the constant value of K does not vary.

\section{ACKNOWLEDMENTS}

Greeting my gratitude to Allah SWT who has given the age and health so that this research can be conducted. Thanks also authors say to parents as a source of spirit. Also on this occasion the authors thank profusely to the friends to contribute ideas and constructive feedback for the perfection of this study. And also, do not forget the authors say to students who have 
been helping with the completion of this study. To Bapak Dr. Ir. H. Komala Pontas that has been offered an opportunity for authors to work and do a lot of things for the progress and selfdevelopment.

\section{REFERENCES}

[1] Agus, Indra, 2011. Comparison of Hydrograph Theoretical Unit to Hydrograph Observation Unit Watershed Ciliwung Hulu, Department of Civil Engineering Polytechnic Affairs Pandang.

[2] Asdak, Chay. 2010.Hydrology and Watershed Management. Gadjah Mada University Press, Yogyakarta.

[3] BAPPEDA Nagan Raya District (2016)

[4] Google 2016, DAS Krueng Seuangan, viewed Juli 2016, avaible from internet.http://www.leuserfoundation.org/index.php?option=com_conte nt \&view=article\&id=175\&Itemid=112. 18 juli 2016

[5] Soemarto, C.D. 1993. Hydrology Technique. Erland. Jakarta

[6] Sobriyah Dan Sudjarwadi, 2000. Merging O'donnel and Cunge Muskingum Methods for Flooding on River Networks. Media Engineering 45.

[7] Triatmodjo, Bambang, 2010. Applied Hydrology. Offset Beta. Yogyakarta 